\title{
The Effect of Transformational Leadership, Personality and Job Satisfaction to Lecturers' Organizational Commitment
}

\author{
Maria Titik Windarti ${ }^{1}$, Thamrin Abdullah ${ }^{2}$, Rita Retnowati ${ }^{3}$ \\ Post Graduate Program, Universitas Pakuan Bogor, Indonesia \\ ${ }^{1}$ mariasukarna@yahoo.com, ${ }^{2}$ thamrin.unpak@yahoo.com, ${ }^{3}$ rita.unpak@yahoo.com
}

\begin{abstract}
The study aims to examine the influence of, transformational leadership, personality and job satisfaction on lecturers' organizational commitment. The variables of transformational leadership, personality and job satisfaction were treated as independent variables while the dependent variable is lecturers' organizational commitment. The study was conducted on purposively selected 94 lecturers of Theological College in the city of Bekasi, West Java, Indonesia. Using mix method, sequential explanatory design is applied where quantitative come first. The study both quantitatively and qualitatively reveals that there is a positive significant relationship among variables under the following distribution of coefficient of correlation: transformational leadership to lecturers' organizational commitment $=0.582$, personality to lecturers' organizational commitment $=0.169$, job satisfaction to lecturers' organizational commitment $=0.267$ and when tested together it produces coefficient of correlation $=0.55$ indicating the existence of other $45 \%$ variables not including in the model affecting organizational commitment in the theological college' lecturers working environment.
\end{abstract}

Keywords: Organizational Commitment, Transformational Leadership, Personality, Job Satisfaction

\section{INTRODUCTION}

Commitment to the organization is something very important in an organization, including in a college organization. Without a high commitment to organizations, lecturer will not perform the duties and responsibilities well. This way, lecturers should be able to maintain the good name, dignity and honor of the profession as well as the organization or university where lecturers are teaching. It is undeniable that many lecturers who have not been able to meet all of the qualifications listed in the law and its enhancements reflecting that the lecturers are less committed to the organization. This notion is proved with the initial findings of the pre-study undertaken on loyalty of the lecturers where they did not show their best reflected in low concern toward 1) participation in the activities of agencies / institutions 2) loyalty to remain as members of the organization. 3) the involvement of lecturers in their duties. 4). being proud as a member of the organization, and 5) the participation of faculty in every activity in the school campus.

Many things affect on organizational commitment such as: organizational leadership, organizational culture, personality of lecturers, work motivation, job satisfaction, and organizational facilities. The quality of a leader is often regarded as the most important factor of success or failure of any organization, including education-oriented organization. So important is the role of leader so that the issue of the leader becomes a factor that attracted the attention of researchers in the field of organizational behavior. University leaders need to do coaching to the lecturers and also pay attention to job satisfaction of the faculty and staff in order to improve the organizational commitment and high job satisfaction. In all organizations, including education, employee performance in faculty is heavily influenced by the leadership of the college leaders. If the leader does not have the ability to lead, the complex tasks cannot be done properly.

Based on the background and the results of the identification of the problem, the formulation of the problem is:

Does transformational leadership positively affect theological college lecturers's organizational commitment?

Does personality positively affect theological college lecturers's organizational commitment?

Does job satisfaction positively affect theological college lecturers's organizational commitment? 


\section{LITERATURE REVIEW}

Bernard M. Bass and Ronald E. Riggio (2006) defines transformational leadership as behavior which can stimulate and inspire followers to achieve results in the process of developing leadership skills, vision and goals given organization, to challenge itself to innovate, solve problems, and develop the ability of the leadership to subordinates through guiding, mentoring, ,challenging and supporting. "Transformational leaders, on the other hand, are then those who stimulate and inspire followers both in achieving extraordinary outcomes and developing their own leadership capacity".

Yukl (2006) stated that transformational leadership is the behavior of a leader who is able to call on his followers moral values in their efforts to raise awareness of ethical issues and mobilize energy and resources to reform institutions. Factors associated with the above definition are: 1) communicating the vision, 2) expressive, 3) a risk taker and sacrificed himself, 4) communicating high expectations, 5) consistent behavior vision, 6) managing the respect of subordinates against leadership, 7) establishing the existence of a group or organization, 8) empowering subordinates.

Based on the theories mentioned above, it can be synthesized that transformational leadership is the behavior of a leader who can inspire subordinates (teachers) to commit to the vision of the school, communicating, motivating, directing, empowering subordinates, to be a model, developing the potential of subordinates as well as a new perspective in solving the problem. The dimensions and indicators are : 1) the influence of the ideal toward subordinates, 2) the inspiration that motivates, 3 ) intellectual stimulation, 4) treatment of subordinates, 5) communication skills, 6) the giver of challenge and support.

This study used the five-factor model of personality, frequently referred to as thebig five to represent normal range personality (Digman, 1990). The big five provides awell-accepted taxonomy that enhances understanding of the relation between personality constructs and important organizational criteria. The construct labels and representative traits of the big five are:(1) extraversion (sociable, talkative, active, and ambitious);(2) agreeableness (sympathetic, warm, kind, cooperative);(3) conscientious (dependable, organized, and persistent);(4) emotional stability (calm, unemotional, secure, and not angry); and (5) openness to experience (imaginative, cultured, broad minded, and flexible). As the introduction and general acceptance of the five-factor model also known as the big fiv research examining the link between personality and work behavior has intensified. The big five dimensions have been replicated in an impressive series of studies across countries and cultures and remain fairly stable over time (Rajiani, 2012).

Rue and Byars (2007) defines job satisfaction as an employee's general attitude towards work. This can be affected by factors such as working conditions, pay and benefits, employee attitudes towards the organisation, supervision of the work, the age and health. That mindset can be negative or positive depending on the mindset of the employees toward the main components of job satisfaction. Rue and Byars give us the understanding that job satisfaction does not come naturally for granted; but many factors that cause an employee be satisfied. Robins and Judge (2012) defines that job satisfaction is evaluative statement either for pleasure or unpleasure toward individual objects or events. Discontent is essentially a person's assessment of the work. Many factors affect employee satisfaction, including: salaries, allowances, achievement, autonomy, recognition, communication, working conditions, the importance of work, coworkers, professionalism, organisational climate, interpersonal relationships, working for a prominent institutions, supervisory support, positive activity, job security, workplace flexibility, working in a cohesive team and genetic factors. Low work satisfaction is associated with the laborious tasks such as documentation, repetition task, the tension in the role expectations, ambitious role, conflicted role, feeling overloaded, increasing the need to be available for overtime, a co-worker relationships, personal factors and organisational factors.

According to Cohen (2006), organisational commitment "as a research topic is important regardless of its setting because a better understanding of the phenomenon may help us to better understand the nature of the psychological process through which people choose to identify with different objects in their environment and how they find purpose in life". Allen and Meyer (2000) identify some variables as an antecedent of organizational commitment. This suggests the need for a research study that will determine the relationship between transformational leadership, personality and job satisfaction and organisational commitment. Various authors have discussed a possible theoretical link between organizational commitment and organisational culture. It appears as if organisational culture tends to 
influence employees' work effort and commitment directly through cultural values, and indirectly through human resources practices (Manetje, \& Martins, 2009). Findings by, Chatman, Caldwell and O'Reilly (1999) suggest that individuals who fit the organisational culture are those who are committed at a normative or value-based commitment dimension; while Nystrom (1993) states that a correlation between organisational culture and organisational commitment indicates that people who work in a strong culture feel more committed. It appears from the research that there is a link between Transformational Leadership, Personality and Job Satisfaction to Organizational Commitment; however, no evidence was found to suggest that similar research studies had been conducted among lecturers of Theological Colleges in Indonesia which notably the organizational culture and management practices are different from western counterpart.

Based on the the literature review the following hypothesis is formulated:

1. Transformational leadership positively affects theological college lecturers'organizational commitment.

2. Personality positively affects theological college lecturers's organizational commitment.

3. Job satisfaction positively affect theological college lecturers's organizational commitment.

\section{Data Collection}

This study applies mix method with direct observation to the field aimed at analyzing the phenomenon occur when the research took place then confirm the finding by using direct depth interview. This way, writers apply Sequential Explanatory Mixed Methods. Descriptive statistics and quantitative analysis are used for finding initial solution to the problem encountered. The sample of this study were 94 theological college lecturers having academic ranks of lecturers up to senior lecturers located in Bogor, West Java Indonesia.

Techniques of data collection in this study is in the form of questionnaire. The normality assumption is prerequisites to proceed to further test. Analysis is conducted with multiple linear regression and hypothesis testing is performed at a significance level of 0.05 .

\section{RESUlT AND DISCUSSION}

The teachers of listed organisations were asked to participate in the survey by responding their opinions for four different measures in Transformational Leadership, Personality and Job Satisfaction to Organizational Commitment. The normality is performed with Lilliefors test. Data are normally distributed as the value of each variable is not exceeding the critical value for Lilliefors test. The Lilliefors normality test values for Transformational Leadership, Personality Job Satisfaction and Organizational Commitment are $0.903,0.898$ and 0.839 respectively below the critical value of 0.914 for $\mathrm{n}=94$.

\subsection{The Effect of Transformational Leadership to Organizational Commitment}

Hypothesis testing confirms that transformational leadership positively affects organizational commitment with correlation coefficient value of 0.583 and the coefficient of determination $=0.339$ with $\mathrm{t}$ test $=9.983$ at $95 \%$ level of confidence. This means that only $33.9 \%$ of organizational commitment is determined by transformational leadership, while the other $66.1 \%$ is contributed by other variables. Similarly, result of qualitative research interviews, observation and documentation confirms the tendency of the relationship between transformational leadership with organizational commitment. This finding strengthens the quantitative research hypothesis results testing that there is a positive significant relationship between transformational leadership and organizational commitment.

This finding is in line with Yukl (2006) that transformational leadership is the behavior of a leader who is able to call on his followers moral values in their efforts to raise awareness of ethical issues and mobilize energy and resources to reform institutions in postulating employees' point of view in creating mode of confidence, value and hope for organizational betterment.

\subsection{The Effect of Personality to Organizational Commitment}

Hypothesis testing confirms that personality positively affects organizational commitment with correlation coefficient value of 0.169 and the coefficient of determination $=0.028$ with $\mathrm{t}$ test $=3.871$ at $95 \%$ level of confidence. This means that only $2.8 \%$ of organizational commitment is determined 
by personality, while the other $97.2 \%$ is contributed by other variables. Similarly, result of qualitative research interviews, observation and documentation confirms the tendency of the relationship between personality with organizational commitment. This finding strengthens the quantitative research hypothesis results testing that there is a positive significant relationship between personality and organizational commitment. Personality has a very strong role within a lecturer in performing their duties. Personality traits can help a person in the selection process as a lecturer, adjust the field of employment, and help people in career development. The pattern of thoughts and feelings and mentality will affect lecturers in adapting to their environment. This is consistent with the theory put forward by Greenberg and Baron (2008) stating that personality is a pattern that is unique and relatively stable behavior, thoughts, and emotions, which is shown by the individual.

\subsection{The Effect of Job Satisfaction to Organizational Commitment}

Hypothesis testing confirms that job satisfaction positively affects organizational commitment with correlation coefficient value of 0.267 and the coefficient of determination $=0.071$ with $t$ test $=6.088$ at $95 \%$ level of confidence. This means that only $7.1 \%$ of organizational commitment is determined by job satisfaction, while the other $92.9 \%$ is contributed by other variables. Similarly, result of qualitative research interviews, observation and documentation confirms the tendency of the relationship between job satisfaction with organizational commitment. This finding strengthens the quantitative research hypothesis results testing that there is a positive significant relationship between job satisfaction and organizational commitment. This is consistent with the theory put forward by Robbins and Judge (2012) that define job satisfaction as a positive feeling about the work of someone which is the result of an evaluation of the nature of the particularities of the organization's members. Therefore the faculty job satisfaction is a very important factor in an institution for the achievement of job satisfaction as the lecturer will show loyalty to the institution in form of commitment when they are satisfied.

\subsection{Interaction of Transformational Leadership, Personality and Job Satisfaction to Organizational Commitment}

When tested together, hypothesis testing results show that there is a significant relationship between Transformational Leadership, Personality and Job Satisfaction to Organizational Commitment. The regression equation generated is $\hat{Y}=120.54+0.582 \mathrm{X}_{1}+0.169 \mathrm{X}_{2}+0.267 \mathrm{X}_{3}$ with correlation of coefficient values $=0.664$ and the coefficient of determination $=0.440$. This means that $44 \%$ of organizational commitment is caused by variables of transformational leadership, personality and job satisfaction while 54\% is contributed by other variables not included in the model. Result of qualitative research interviews, observation and documentation in the respective college also confirms the relationship among transformational leadership, personality and job satisfaction to organizational commitment. This finding strengthens the quantitative research hypothesis results testing that there is a positive significant relationship among those mentioned variables. Qualitative research also reveals that other factors affecting organizational commitment in the respective school are school's facility and lecturers' welfare which is viewed as less optimal.

\section{CONCLUSION}

The findings reveal that there is a positive and significant direct effect between the transformational leadership, personality and job satisfaction to organizational commitment.

Based on the initial design of the constellation between variables, the results showed that the contribution of transformational leadership to organizational commitment is $33.9 \%$, personality is $2.8 \%$, and job satisfaction is $7.1 \%$ indicating the highest individual contribution to the lecturers' organizational commitment is transformational leadership. When combined together, contribution of the three variables reaches $44 \%$ indicating the contribution of other variables not included in the model to predict organizational commitment are $56 \%$ confirming this model is of marginal-fit. Other researchers wishing to conduct similar studies may include other variables such as; lecturers' professionalism, achievement motivation, work culture of lecturers, lecturers' resilience, creativity, work experience, training, management, decision-making techniques and so forth. This confirms Rajiani (2012) discernment that it is required to conduct an inclusive and critical investigation to identify the factors that heighten and boost organizational commitment. Factors related to personal characteristics, organizational environment, and leadership behaviors recovered to foretell various types of organizational commitment mainly within theological college' context which are hardly investigated. 


\section{REFERENCES}

Allen, Natalie J., and John P. Meyer (2000). "Construct validation in organizational behavior research: The case of organizational commitment." In Problems and solutions in human assessment, pp. 285-314. Springer US.

Bernard M., Bass dan Ronald E. Riggio (2006). Transformational Leadership-2 ${ }^{\text {nd }}$ ed. New Jersey: Lawrence Erlbaum Associates,

Chatman, Jennifer A., David F. Caldwell, and Charles A. O'Reilly (1999). "Managerial personality and performance: A semi-idiographic approach." Journal of Research in Personality 33, no. 4 $.514-545$.

Cohen, Aaron (2006). "The relationship between multiple commitments and organizational citizenship behavior in Arab and Jewish culture." Journal of Vocational behavior 69, no. 1, pp. 105-118.

Digman, J.M. (1990) Personality structure: Emergence of the five-factor. Annual Review of Psychology 1: 417-440.

Greenberd, Jerald dan Robert A. Baron (2008). Behavior In Organization Understanding a Man aging The Milian Side of Work. Ninth Edition,Boston: Allyn and Bacon.

Manetje, O., and Nico Martins (2009). "The relationship between organisational culture and organisational commitment." Southern African Business Review 13, no. 1, pp. 87-111.

Nystrom, Paul C. (1993)."Organizational cultures, strategies, and commitments in health care organizations." Health Care Management Review 18, no. 1, pp.43-49.

Rajiani, Ismi (2010). "Applying Personality Traits to Predict Loyalty and Neglect among Employees of Bank Jatim Located in 10 Big Cities of East Java (Mc Crae's and Hofstede's Theories on effect of Culture to Personality Revisited)." Jurnal Aplikasi Manajemen 8, no. 3, 2012, pp-617623.

Rue, Leslie W. and Lioyd L Byars (2007). “Supervision Key Link to Productivity”. New York: Mc Graw Hill, pp.123.

Robbins, S. P. \& T. A. Judge (2012). Organizational Behavior. New Jersey: Pearson Education,

Yukl, Gary (2010). Leadership in Organizations $-7^{\text {th }}$ ed. New Jersey: Pearson Education, Inc, Upper Saddle River. 